\title{
In Memoriam - Dr. Consolacion Y. Ragasa
}

\author{
Wyona C. Patalinghug, Drexel H. Camacho*, Jaime Raul O. Janairo*, Lourdes P. Guidote, \\ Maria Carmen S. Tan, Jasmine Ting, Vincent Antonio S. Ng
}

Chemistry Department, De La Salle University, 2401 Taft Avenue, Manila 0922, Philippines

*Author to whom correspondence should be addressed; email: jaime.janairo@dlsu.edu.ph, drexel.camacho@dlsu.edu.ph

\begin{abstract}
On April 14, 2021, the Philippine chemistry community lost one of its most prolific researchers due to the COVID19 virus. Herein we reflect on the extraordinary life and work of Dr. Consolacion Y. Ragasa. We highlight her story, her scientific contributions, and the huge impact she left, not only on her students and colleagues but also on the scientific research community.
\end{abstract}

Keywords: Consolacion Ragasa; natural products chemistry; secondary metabolites; NMR; Philippine chemistry

\section{INTRODUCTION}

Dr. Consolacion Y. Ragasa, or Connie as called by her close friends, passed away in Manila after battling for 18 days the new coronavirus disease COVID-19, on April 14, 2021, at the age of 65 . Dr. Ragasa was a University Fellow and Full Professor at the Chemistry Department, De La Salle University. She was the leading scientist in Natural Products research in the country. At the time of her death, her publication records in Scopus-listed journals totaled 238 papers with an h-index of 23 (Scopus.com). She was a recipient of various awards such as the Pillar of Lasallian Excellence Award in Research (2013), National Research Council of the Philippines (NRCP) Achievement Award in Chemical Research (2003), and the Philippine Federation of Chemistry Societies (PFCS) Achievement Award in Chemical Research (2002). Her career was devoted to natural products research which included isolating, purifying, and elucidating the chemical constituents mostly from Philippine endemic plants. She has mentored numerous undergraduate and graduate students, where she emphasized hard work, dedication, and immersion in the laboratory to gain competence and excellence. 


\section{HUMBLE BEGINNINGS}

Born as a sickly baby in Sinait, Ilocos Sur on August 28, 1955, Dr. Ragasa started schooling at Kalantiyaw Elementary School (Project 4, Quezon City; Grades 1-2; AY 1962-64), then finished her elementary education at Pura V. Kalaw Elementary School (Project 4 Quezon City; Grades 36; AY 1964-68). She studied in Palawan National High School (Puerto Princesa) for a year (196869) when the family moved to Palawan due to her father's job, but returned to Project 4, Quezon City when her father got sick. She transferred to Centro Escolar University High School (Mendiola St., San Miguel, Manila; AY 1969-72) to complete her high school education. She obtained her BS, MS, and Ph.D. Chemistry degrees from UP-Diliman in 1977, 1983, and 1990, respectively. Her science career started as a Science Research Associate at the Natural Sciences Research Institute (NSRI) (1978-1979), then she transferred to the Department of Science and Technology (DOST formerly National Science and Technology (NSTA) until 1987) initially as a Planning officer (1980-1981), then as a Science Research Specialist (1982-1983). She started her stint at De La Salle University as a part-time Lecturer in AY 1981-1992 for two terms, then joined again as an Assistant Professor in AY 1983-1984 after finishing her MS degree under the tutelage of the late National Scientist Dr. Clara Lim-Syliangco. She was granted study leave from 1984-1988 as part of the $2^{\text {nd }}$ batch of the Science and Mathematics Consortium program of the UP-Ateneo-De La Salle $\mathrm{Ph}$.D. Consortium funded by DOST for the breeder sciences. The program produced several Ph.D. graduates who are now holding key academic, research, and administrative positions in local universities and research centers (Saloma, 2011). In the same batch as Dr. Ragasa in the Consortium are the prominent natural products chemists Dr. Alice Aguinaldo of UST, Dr. Irene Villaseñor of the UP Institute of Chemistry, and Dr. Amelia Guevara of UP, who later became DOST Undersecretary (2012-2016). Dr. Florenda Valera, the analytical chemist from UP, was also in her batch.

Being curious about the ability of herbal remedies, she decided to specialize in natural products chemistry for her Ph.D. and worked on Wedelia prostate, an herbaceous vine common in the Philippines, which is widely used as a hair tonic/colorant and treatment for coughs, skin diseases, and uterine hemorrhages (Ragasa, Padolina, Bowden, et al., 1993). For her dissertation, Dr. Ragasa was mentored by Dr. William Padolina of UPLB who later became Secretary of the DOST in 1994-1999. The Consortium partnered with the Australian Universities International Development Program (AUIDP) and the Japan Society for the Promotion of Science (JSPS) and the scholars were sent either to Australian or Japanese universities as part of their Ph.D. training. Dr. Ragasa was sent to James Cook University in Northern Queensland in the laboratory of Dr. John Coll where she stayed for 6 months. Dr. John Coll became her co-adviser and was a major influence in her career. As part of her Ph.D., she also worked with Japanese researchers on Pseudoelephantopus spicatus (aka false elephant's foot) another herbaceous plant common in the Philippines, which is used as a topical agent for eczema and as an anti-inflammatory agent applied for snake bites (Ragasa, Padolina, Yamauchi, et al., 1993). It may be a surprise to many that it took Dr. Ragasa some time to write up her dissertation. She had finished her experimentation on time and what was left to do was the write-up. Her grant/study leave was only until 1988 and she returned to her teaching duties that year at DLSU. But like many other Ph.D. candidates, she somehow hit a wall. Some older members of the DLSU Chemistry Department recalled the coaxing, persuading, and inveigling by friends, mentors, and colleagues for her to start writing up her dissertation. Eventually, she finished and graduated in 1990. While Dr. Ragasa obtained a UP diploma, her training was from the Consortium universities, which undoubtedly influenced her. She was able to publish her manuscripts from her disserationin 1993, five years after collecting the data. She reported new eudesmanolide sesquiterpenes and germacranolides from $W$. prostata and $P$. spicatus, respectively. Her subsequent publications started in the DLSU-College of Science journal, Agham, in KIMIKA - the Journal of the Philippine Chemical Society (Kapisanang Kimika ng Pilipinas), and in the Philippine Journal of Science. It was only in 1997 when her publications 
in international journals started picking up. From then on, there was no turning back; her publication rate accelerated. She had found her groove. At the time of her death, she had over 300 publications (Scopus data: 280 publications with 1981 citations and h-index of 23; Google Scholar data: 389 publications with 3484 citations and h-index of 30). Remarkably, she remembered all the plants she had studied! She forgets the name of her students but she remembered the plants they worked on and the compounds isolated from them.

Dr. Ragasa's impressive scientific productivity driven by an outstanding talent earned her an Associate Professorship and Full Professorship positions in 1991 and 1998, respectively. Due to her distinguished research outputs and contributions to the university, she was inducted into the DLSU Society of Fellows and conferred the title of University Fellow in AY 2000-2001. This award is only given to select university faculty in recognition of their distinguished teaching, research, publication in their field of study, and their meritorious service to the University.

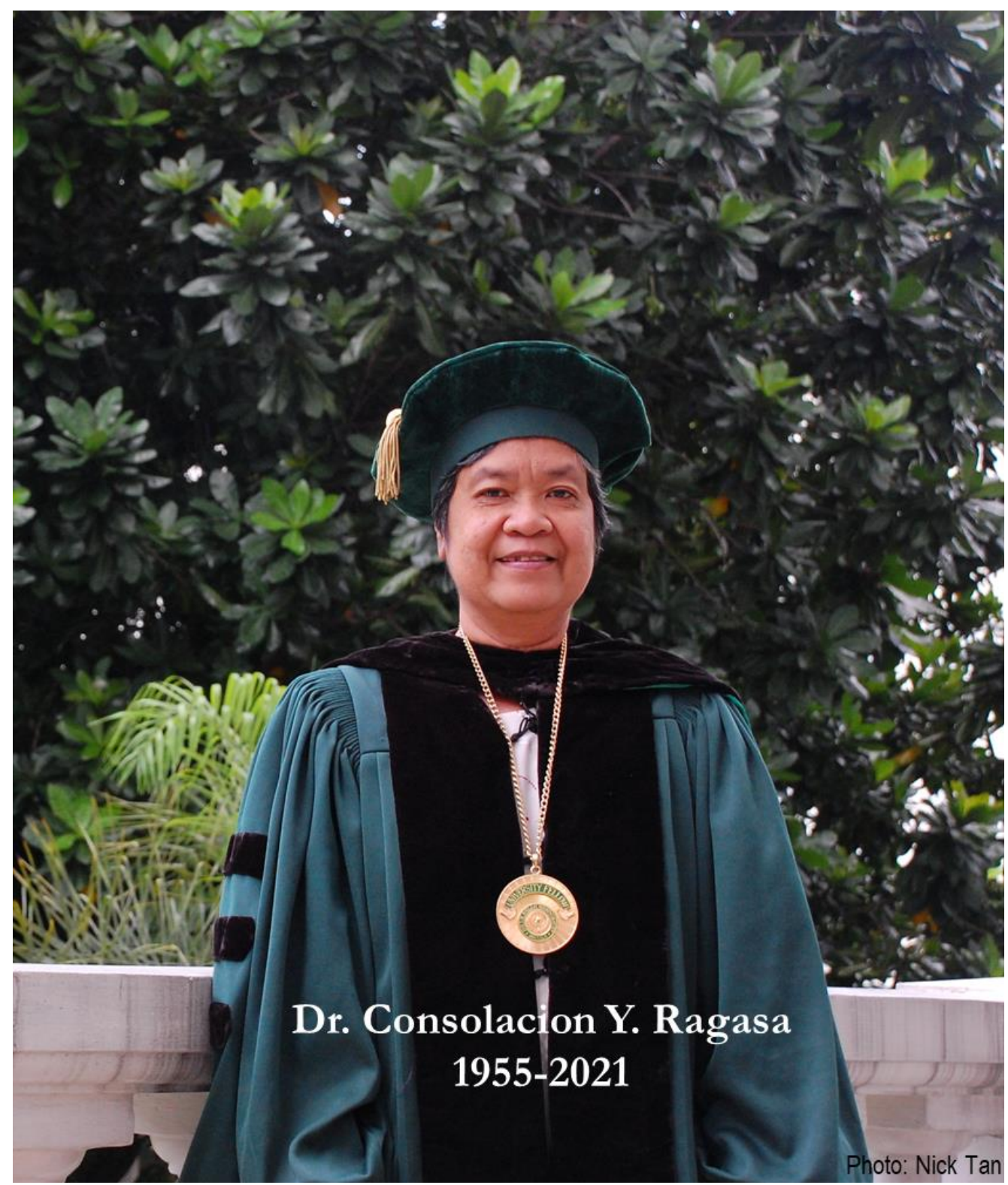

Figure 1. Dr. Consolacion Y. Ragasa (1955-2021) in a DLSU University Fellow academic toga taken at De La Salle University in Taft Avenue, Manila, Philippines, circa 2011, behind the "Centennial" Tree, Barringtonia asiatica, which she extensively studied for its chemical constituents. Photo courtesy of Nikki Andrei V. Tan. 


\section{THE NMR WIZ}

It is hard to pinpoint exactly when or what ignited her passion in her work after a relatively long lag time. Although it can be surmised that the confidence her advisers had in her ability had something to do with it. Dr. John Coll, her co-adviser, visited the DLSU Chemistry Department annually as part of his AUIDP duties. He brought with him some colleagues to give seminars and provide the department with collaborators in research. Dr. Ragasa had exceptional skill, almost an artistry, for isolating compounds from plants. Her compounds were terpenes and flavonoids. However, she could not go any further towards their structural elucidation because there was no Nuclear Magnetic Resonance (NMR) instrument in the country at that time.

Dr. Coll was very instrumental in introducing Connie to his colleague Dr. John Rideout, an NMR specialist. To complete the compound structure, Connie would isolate the terpenes, then send the isolates to Dr. Rideout in Australia for the NMR runs. The resulting spectra were then sent back to her for interpretation. With the NMR spectra on hand, she was able to see the full picture and elucidate the full structure of her isolates. Dr. Ragasa and Dr. Rideout collaborated in many of her earlier papers. Eventually, she found other collaborators such as Dr. Chien-Chiang Shen from the National Institute of Chinese Medicine in Taipei, Taiwan with whom she has published much of her later works.

Dr. Ragasa's middle initial is Y for Yasaña. Her full name is Consolacion Y. Ragasa. But for those who have worked with her, her middle initials could easily have been NMR. It refers to Nuclear Magnetic Resonance (NMR), the technique used by organic and natural product chemists for the structural elucidation of compounds and chemical isolates. NMR was her "bukambibig". By understanding the behavior of the compound when subjected to the magnetic field, she was an excellent translator of any NMR spectra that would fall on her lap. She could identify familiar compounds by just glancing at the spectrum. She talked about it with so much passion, especially when she elucidated the structure using extensive 1D and 2D NMR techniques. She could talk about her NMR analysis to no end with an excitement of a child, such that colleagues and students considered it a skill to successfully butt in during her animated sharing or discussion.

All her structural elucidations were done by NMR and she was always needling the department and the college to buy an NMR - a very expensive instrument so vitally needed in a chemistry department. In 2018, DLSU acquired this dream machine, which is now installed in the Laguna campus. This pleased her so much (Figure 2). After years of sending samples to collaborators abroad for NMR measurements, she was finally able to publish papers with no international collaborators to do the NMR work. All her NMR analyses could now be done at DLSU. Dr. Ragasa had realized her dream.

\section{THE ACADEMIC MOTHER: A PASSIONATE RESEARCHER, MENTOR, AND TEACHER}

Dr. Ragasa devoted the majority of her time working in the laboratory with students and mentoring young natural products researchers in DLSU. She established herself as one of the most published and highly cited academic researchers in the country. She has played a major role in shaping the Natural Products Research strength of the department through multidisciplinary and collaborative research. Her most cited work is the paper on the bioactive triterpene from Lantara camara, which she co-authored with Dr. Bruce Bowden and Dr. John Coll from James Cook University in North Queensland, DLSU colleague Dr. Gerado Janairo, and DLSU students Juanita Barre, Joanna de Jesus, and Victoria dela Fuente (Barre et al., 1997). The paper has been cited 95 times since its publication. Two papers both describing new furanoid diterpenes from Caesalpinia pulcherrima garnered 76 and 64 citations at the time of her death. The first paper was a 
collaborative work with Dr. John Rideout from James Cook University and graduate student Joy Hofileña (Ragasa et al., 2002); while the other one involves Dr. Rideout who moved to the Central Queensland University in Australia, and DLSU graduate students Jerome Ganzon, Joy Hofilena, and Benjie Tamboong (Ragasa et al., 2003).

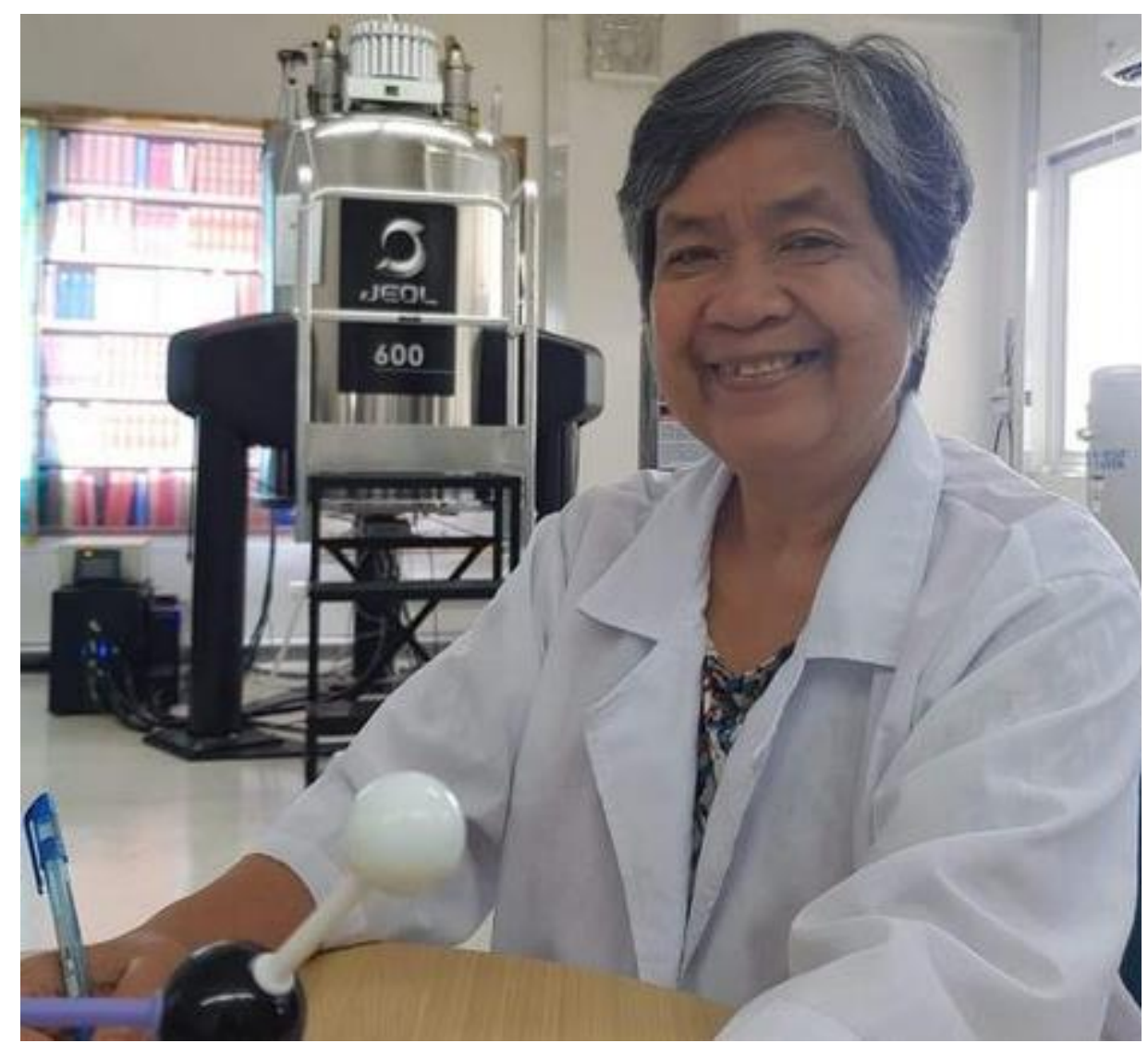

Figure 2 Dr. Ragasa with the newly installed $600 \mathrm{MHz}$ NMR instrument in the background, circa 2019. Photo courtesy of Drexel H. Camacho.

In her almost four decades in DLSU, she has mentored 7 Ph.D. students, several MS students, and hundreds of undergraduate students. Together with her students, she has reported a total of 63 new and novel compounds from various Philippine natural sources (Figure 3). Aside from terrestrial plants, she also worked on mushrooms, algae, mosses, lichens, marine organisms, and insects. Dr. Connie could have named the compounds after herself but she never did. She said, "Di ba gawa ng Diyos and mga halaman na 'yan? The glory should belong to God."

Over the years, the collaborators of Dr. Connie were not limited to the field of natural products but extended to other areas of chemistry and biology. This allowed Dr. Connie to be involved with more research that enhanced the drug discovery process. Looking back at the roles and achievements that she had reached within the scientific community, Dr. Connie was a "bridge" for multidisciplinary research. She served as a mentor for young scientists interested in natural products, a collaborator for scientists from different fields, and an ambassador for NMR. Table 1 presents the top 15 collaborators (students or colleagues) of Dr. Ragasa who were based in the Philippines at the time of the collaboration. 

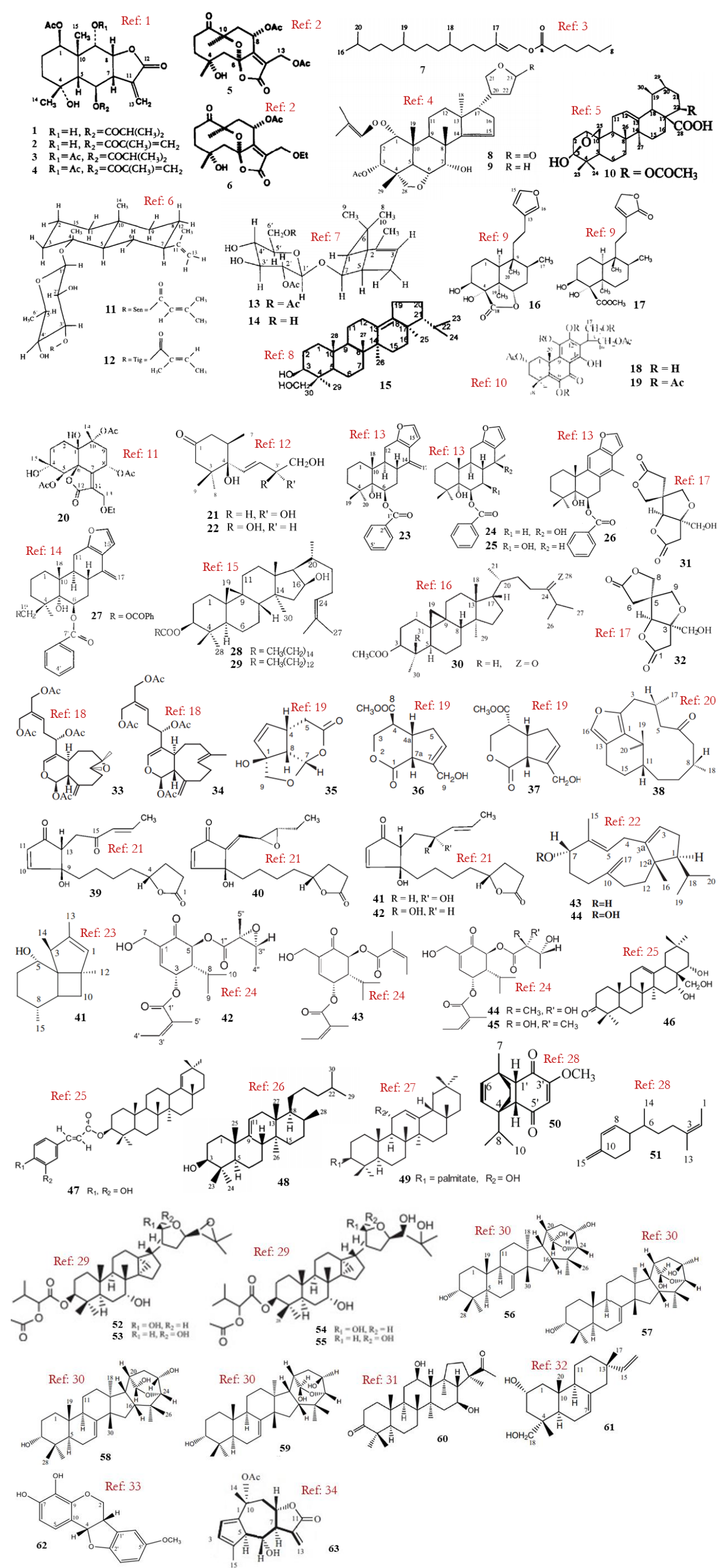

Figure 3: The new and novel compounds reported by Dr. Ragasa obtained from Scopus-listed journals. (Note: Numbered references are listed separately in the Reference section) 
Table 1: List of Top 15 Students and Philippine-based Collaborators of Dr. Ragasa from Scopus data

\begin{tabular}{|l|l|l|}
\hline $\begin{array}{l}\text { DLSU students and } \\
\text { Philippine-based } \\
\text { Collaborators }\end{array}$ & $\begin{array}{l}\text { Affiliations at the time of paper } \\
\text { publication }\end{array}$ & $\begin{array}{l}\text { Number of co- } \\
\text { authored papers }\end{array}$ \\
\hline Ng, Vincent Antonio S. & De La Salle University & 45 \\
\hline Tan, Maria Carmen S. & De La Salle University & 43 \\
\hline Agoo, Esperanza Maribel G. & De La Salle University & 32 \\
\hline de Los Reyes, Mariquit M. & De La Salle University & 27 \\
\hline Mandia, Emelina H. & De La Salle University & 26 \\
\hline Ebajo, Virgilio D. & De La Salle University & 25 \\
\hline Raga, Dennis D. & Ateneo de Manila University & 25 \\
\hline Espineli, Dinah L. & De La Salle University & 17 \\
\hline Oyong, Glenn G. & De La Salle University & 17 \\
\hline Torres, Oscar B. & De La Salle University & 16 \\
\hline Alimboyoguen, Agnes B. & De La Salle University & 9 \\
\hline Herrera, Annabelle A. & University of the Philippines, Diliman & 9 \\
\hline Aurigue, Fernando B. & Philippine Nuclear Research Institute & 8 \\
\hline De Castro-Cruz, Kathlia A. & Mapua University, Manila & 7 \\
\hline Bernardo, Leonisa O. & $\begin{array}{l}\text { Southern Luzon State University, } \\
\text { Lucban, Quezon }\end{array}$ \\
\hline
\end{tabular}

As a teacher, she was best known among her students as a strict, yet compassionate mentor who demanded consistent excellence in all aspects of work. Dr. Connie was an achiever, but she never forgot her role as a mentor and teacher. She never tried to hide her imperfections as a senior scientist. With the experiences that she had, Dr. Connie understood the needs and struggles of her students. She was more than willing to share her knowledge, not only in doing research, but the wisdom to use this knowledge for the benefit of others. Dr. Connie believed that sometimes challenging her students would help them grow and persevere. As she said during an interview in 2015 , "The more I am challenged, the harder I work."

Whenever Dr. Connie saw unique plant samples or challenging NMR spectra, her excitement would betray her as she attempted to unveil the chemical constituents behind the leaves and the secrets behind the NMR peaks. Her dedication to the chemistry of natural products grew correspondingly with the increasing number of publications. Her advisees would see her working in the laboratory alongside them, starting at the crack of dawn until 10:00 pm. Dr. Connie helped lessen the workload of her students by patiently showing them how to process some of the fractions within a set, how to interpret NMR spectra, or how to write their thesis/dissertation. She would dedicate a special amount of attention to each student, revealing her passionate approach to mentoring. On top of this, she was generous with sharing her research grants with her students for any of their needs and expenses. Her kindness and care for her students were not limited to the walls of the laboratory and classroom. She would initiate communication to learn the progress and/or understand the problems encountered by her students. She would offer anything she could do for her students.

She was known to utilize all her available time to do research. Her daily commute with students from DLSU Laguna campus to Manila was not wasted because they would continue to interpret NMR spectra despite the bumps and turbulence during the 1-hour commute. Her dedication is legendary because even in her public commute going home to Quezon City from DLSU Taft campus using FX or LRT, she used the time to interpret NMR spectra while commuting. Words that usually came out of her mouth are: "I can isolate stigmasterol/sitosterol in 2 hours", "Uy collect mo na yang band na yan. Pure yan!", Talking to a plant "Uy alam ko kung ano mga compounds mo!", 
"Looking at your ${ }^{1} H$ NMR spectrum, it would seem that your compound has an impurity of this and that", "Your interpretation on the multiplicity is incorrect. This proton should be coupled to this and that" (Macabeo, 2021). Her child-like excitement is very evident every time a new publication comes out as she celebrates the success with her students. All of these anecdotes were noted by the students which exemplifies how much her mentorship will be sorely missed.

\section{ELEVATING PHILIPPINE NATURAL PRODUCTS RESEARCH IN INTERNATIONAL MAP}

Due to the extensive research output of Dr. Ragasa, she was listed in Marquis Who's Who for Contributions to the Field of Science (2011), Leading Scientists of the World (2011), Outstanding Scientists of the 21st Century (2007), Marquis Who's Who in the World (2007) and Marquis Who's Who in Medicine and Health Care (2006). She has served as a member of the Editorial Board for the following international scientific journals: International Journal of Pharmaceutical and Clinical Research (2016), International Journal of Immunotherapy and Cancer Research (2015), Advances in Biomedicine and Pharmacy (2014), The Scientific World Journal (2013), Pharmacologia (2013), Journal of Pharmaceutics (2012), American Journal of Life Sciences (2012), American Journal of Research Communication (2012), and the Journal of Botanics: Targets and Therapy (2010). In the Philippines, she served as a member of the editorial board of Philippine Science Letters (2008), Philippine Journal of Science (2003-2021), and Manila Journal of Science (2000-2002; 2010).

Through her demonstrated expertise, she has formed a network of international collaborators mostly from Taiwan and Australia (Table 2)

Table 2: List of International Collaborators of Dr. Ragasa from Scopus data

\begin{tabular}{|l|l|l|}
\hline $\begin{array}{l}\text { International } \\
\text { Collaborators }\end{array}$ & $\begin{array}{l}\text { Current affiliation of International } \\
\text { Collaborators }\end{array}$ & $\begin{array}{l}\text { Number of co- } \\
\text { authored papers }\end{array}$ \\
\hline Shen, Chien-chiang & $\begin{array}{l}\text { National Research Institute of Chinese Medicine } \\
\text { Taiwan }\end{array}$ & 163 \\
\hline Urban, Sylvia & RMIT University, Melbourne, Australia & 24 \\
\hline Brkljača, Robert & Monash University, Melbourne, Australia & 23 \\
\hline Rideout, John A. & $\begin{array}{l}\text { Central Queensland University Australia, } \\
\text { Rockhampton, Australia }\end{array}$ & 21 \\
\hline van Altena, Ian A. & $\begin{array}{l}\text { The University of Newcastle, Australia, Callaghan, } \\
\text { Australia }\end{array}$ & 9 \\
\hline Don, Ming Jaw & $\begin{array}{l}\text { National Research Institute of Chinese Medicine } \\
\text { Taiwan, }\end{array}$ & 7 \\
\hline Tsai, Po Wei & Chang Jung Christian University, Tainan, Taiwan & 7 \\
\hline Bowden, Bruce F. & James Cook University & 5 \\
\hline Coll, John C. & $\begin{array}{l}\text { Australian Catholic University, North Sydney, } \\
\text { NSW, Australia }\end{array}$ & 4 \\
\hline Chiou, Chuntang & $\begin{array}{l}\text { National Research Institute of Chinese Medicine } \\
\text { Taiwan }\end{array}$ & 2 \\
\hline Li, Wentai & $\begin{array}{l}\text { National Research Institute of Chinese Medicine } \\
\text { Taiwan }\end{array}$ & 2 \\
\hline Tada, Masaru & Waseda University, Tokyo & 2 \\
\hline
\end{tabular}




\section{CONNIE AS A PERSON OUTSIDE THE ACADEMIA}

Being a great scientist and mentor, Dr. Connie was also a loving daughter, a caring sister, a giving friend, and a beloved colleague. Dr. Connie was known to be a workaholic and would only leave the laboratory if she received a call from her mother. Her love and care for her family are the same as her love for research. She often talked about her mother, her family, and her mango plantation. She oftentimes showers the department with sweet mangoes harvested from her farm.

Even with her busy schedule, Dr. Ragasa was interested in the love stories of her mentees. She was very observant of the visitors/suitors who visited her students in the lab. She also exhibited the passion of a collector where she, for some time, was very passionate about jewelry, orchids, pets, and green tea.

Connie will be remembered by everyone in the DLSU Chemistry Department for her generosity. For many years, she has sponsored the annual departmental bowling event. Dubbed as the Ragasa Cup, she tirelessly financed the cost of the bowling events and numerous eating escapades of the department. Despite her generosity to the people she cared for, she was very frugal with regards to expenses for herself. The last movie she watched in a movie theater was Ghost starring Demi Moore, Patrick Swayze, and Whoopi Goldberg released in 1990. She watched the movie in the now-defunct Harrison Plaza together with the Chemistry faculty upon the prodding of the department.

\section{A CONTINUING LEGACY}

It was unfortunate that Dr. Ragasa succumbed to COVID-19. Her life and expertise were a tremendous loss not only to DLSU but to the Chemistry and scientific community. She has mentored numerous DLSU students in her entire career. Her last opus could have been her involvement in the Tuklas Lunas Fellowship Program for Natural Products Research (TLFPNRP) conducted by DLSU and funded by DOST-PCHRD. The Fellowship Program embarked on the conduct of intensive and advanced training in Natural Products at DLSU to 15 Fellows from Tuklas Lunas Implementing Agencies (TLIAs) all over the country (Nazario, 2020; Doctor, 2020). Intensive and advanced training on the following courses: Chemistry of Natural Products, NMR Spectroscopy for Natural products, and Chromatography for Natural Products were conducted highlighting the principles, isolation protocols, and structure elucidation. This Fellowship Program is rooted in the expertise of Dr. Ragasa in Natural Products research, the presence of several chromatographic instruments such as LC-MS/MS QToF, preparative HPLC, and the existence at DLSU of a powerful $600 \mathrm{MHz}$ Nuclear Magnetic Resonance (NMR) spectrometer, which is the crucial instrumentation in the structure elucidation of compounds. During the conception of the Fellowship Program, she was very excited because she could work with various researchers from regional HEIs and that she could demonstrate the utility of NMR to a wide number of researchers outside DLSU. During the Fellowship Program, she handled the "Laboratory" session of the Chemistry of Natural Products course where she laid down all her "secrets" on how she attained the level of expertise she honed through years of misses and successes in the laboratory. Despite the Fellows being outside of her research group, she bared all her tips and techniques to them, no-holds-barred. Fortunately, the lectures and experiential sharing she made during the Fellowship Program were all recorded, which can be used for future students and researchers. The departure of Dr. Ragasa will put a dent in the natural products research of DLSU. Fortunately, she was able to mentor young faculties who can continue her legacy. The natural products group in DLSU will continue with new players such as Dr. Vincent Antonio Ng, Dr. Virgilio Ebajo, Jr., and Dr. Maria Carmen Tan along with some faculty who still do natural products research such as Dr. Jaime Raul Janairo and Dr. Raymond Malabed. 
Indeed, mentoring in science is a very important component in the scientific enterprise. Training young and bright students and junior colleagues will ensure the continuity of research output. The kind of mentoring Dr. Ragasa gave to her students and junior colleagues involved day-to-day technical discussions while doing actual laboratory experiments. She was a workhorse who demanded from her students the same dedication she herself possessed. She always emphasized that attaining expertise in any field requires daily immersion in the lab and diligence in data processing such as reading NMR spectra. Indeed, mentoring is modeling the action, imparting the knowledge unceasingly, putting a little pressure, and celebrating success. The key takeaway we can learn from Dr. Ragasa's mentoring style is doing all of the above CONSISTENTLY with a student. Rest in peace, Dr. Connie Ragasa.

\section{REFERENCES}

Barre JT, Bowden BF, Coll JC, De Jesus J, De La Fuente VE, Janairo GC, Ragasa CY. A bioactive triterpene from Lantana camara, Phytochemistry, 1997 May; 45(2): 321-324. https://doi.org/10.1016/S0031-9422(96)00805-9

Doctor, M. M. (2020) DLSU inaugurates drug discovery program. The Post, Campus News Section, Nov. 6, 2020. https://thepost.net.ph/news/campus/dlsu-inaugurates-drug-discoveryprogram/?fbclid=IwAR3ncL8KaBUZZEZpVg68QbhU025VtLKP1kUMG9RtdUXzqOjtmuf9ad0Yftg

Macabeo, A. P. Facebook post April 15, 2021 1:06 pm. https://www.facebook.com/Wyeth28

Nazario, D. (2020) Capacity-building program for research on natural products underway. Manila Bulletin, National News Section, Oct. 24, 2020. https://mb.com.ph/2020/10/24/capacitybuilding-program-for-research-on-natural-productsunderway/?fbclid=IwAR08IAiMWLm4qu8PVLV-I8PTx8iW4s7aFKcglytboeldUaZ6Ep9tFiIcxFk

Ragasa CY, Padolina WG, Bowden BF, Li S, Tapiolas DM, Coll JC. New eudesmanolide sesquiterpenes from a Philippines collection of Wedelia prostata. J. Nat. Prod. 1993 March; 56(3):386-393. https://doi.org/10.1021/np50093a011

Ragasa CY, Padolina WG, Yamauchi T, Otsuka H, Yamazaki K, Satoh T. Germacranolides from Pseudoelephantopus spicatus. Phytochem. 1993 June; 33(3):627-629. https://doi.org/10.1016/0031-9422(93)85461-Y

Ragasa CY, Hofileña JG, Rideout JA. New furanoid diterpenes from Caesalpinia pulcherrima, J Nat Prod. 2002 July; 65(8):1107-1110. https://doi.org/10.1021/np0201523

Ragasa CY, Ganzon J, Hofileña J, Tamboong B, Rideout JA. A new furanoid diterpene from Caesalpinia pulcherrima. Chem Pharm Bull 2003; 51(10):1208-1210. https://doi.org/10.1248/cpb.51.1208

Saloma, C. The national science consortium, Star Science, Philippine Daily Inquirer, Feb 17, 2011. https://www.philstar.com/business/science-and-environment/2011/02/17/657716/nationalscience-consortium

\section{Numbered references as indicated in Figure 3}

1. Ragasa CY, Padolina WG, Bowden BF, Li S, Tapiolas DM, Coll JC. (1993). New eudesmanolide sesquiterpenes from a Philippines collection of Wedelia prostata. J Nat Prod. 1993 March; 56(3):386-393. https://doi.org/10.1021/np50093a011. 
2. Ragasa CY, Padolina WG, Yamauchi T, Otsuka H, Yamasaki K, Satoh T. Germacranolides from Pseudoelephantopus spicatus. Phytochem. 1993; 33(3):627-629. https://doi.org/10.1016/00319422(93)85461-y.

3. Zulueta MCA, Tada M, Ragasa CY. A diterpene from Bidens pilosa. Phytochemistry, 1995; 38(6): 1449-1450. https://doi.org/10.1016/0031-9422(94)00793-s.

4. Ragasa CY, Nacpil ZD, Natividad GM, Tada M, Coll JC, Rideout JA. Tetranortriterpenoids from Azadirachta indica. Phytochem. 1997; 46(3):555-558. https://doi.org/10.1016/s00319422(97)87092-6.

5. Barre JT, Bowden BF, Coll JC, De Jesus J, De La Fuente VE, Janairo GC, Ragasa CY. A bioactive triterpene from Lantana camara. Phytochemistry, 1997; 45(2):321324. https://doi.org/10.1016/s0031-9422(96)00805-9.

6. Ragasa CY, Rideout JA, Tierra DS, Coll JC. Sesquiterpene glycosides from Pittosporum pentandrum. Phytochemistry, 1997; 45(3):545-547. https://doi.org/10.1016/s0031$\underline{9422(96) 00852-7}$

7. Ragasa CY, Rideout JA, Sy JO, Alcachupas D, Inte VML, Coll JC. Bioactive monoterpene glycosides from Erigeron linifolius. Phytochemistry, 1997; 46(1):151-154. https://doi.org/10.1016/s00319422(97)00223-9

8. Ragasa CY, Juan E, Rideout JA. A triterpene from Ficus pumila. J Asian Nat Prod Res. 1999; 1(4):269-275. https://doi.org/10.1080/10286029908039875.

9. Ragasa CY, Cruz MC, Gula R, Rideout JA. Clerodane Diterpenes from Tinospora rumphii. J Nat Prod. 2000; 63(4):509-511. https://doi.org/10.1021/np9902946

10. Ragasa CY, Templora VF, Rideout JA. Diastereomeric Diterpenes from Coleus blumei. Chem Pharm Bull. 2001 July; 49(7):927-929. https://doi.org/10.1248/cpb.49.927

11. Ragasa CY, Rideout JA. An antifungal cadinanolide from Pseudoelephantopus spicatus. Chem Pharm Bull. 2001 Oct; 49(10):1359-1361. https://doi.org/10.1248/Cpb.49.1359.

12. Ragasa CY, Tremor N, Rideout JA. Ionone derivatives from Alternanthera sessilis. J Asian Nat Prod Res. 2002; 4(2):109-115. https://doi.org/10.1080/10286020290027380.

13. Ragasa CY, Hofileña JG, Rideout JA. New furanoid diterpenes from Caesalpinia pulcherrima. J Nat Prod. 2002; 65(8):1107-1110. https://doi.org/10.1021/np0201523.

14. Ragasa CY, Ganzon J, Hofileña J, Tamboong B, Rideout JA. A new furanoid diterpene from Caesalpinia pulcherrima. Chem Pharm Bull. 2003; 51(10):1208210. https://doi.org/10.1248/cpb.51.1208

15. Ragasa CY, Tiu F, Rideout JA. New cycloartenol esters from Ixora coccinea. Nat Prod Res. 2004 Aug; 18(4):319-323. https://doi.org/10.1080/14786410310001630519

16. Ragasa CY, Ngo HT, Rideout JA. Terpenoids and sterols from Lagerstroemia speciosa. J Asian Nat Prod Res. 2005 Feb; 7(1):7-12. https://doi.org/10.1080/10286020310001596024.

17. Ragasa CY, de Luna RD, Cruz WC, Rideout JA. Monoterpene lactones from the seeds of Nephelium lappaceum. J Nat Prod. 2005; 68(9):1394-1396. https://doi.org/10.1021/np0580053

18. Janairo JRO, Janairo GC, Ragasa CY, Bowden BF. New xenicanes from Xenia viridis. Nat Prod Res. 2007 Oct; 21(12):1067-1072. https://doi.org/10.1080/14786410701589733. 
19. Ragasa CY, Pimenta LEN, Rideout JA. Iridoids from Gardenia jasminoides. Nat Prod Res. 2007 Oct; 21(12):1078-1084. https://doi.org/10.1080/14786410701589998

20. Janairo JRO, Janairo GC, Ragasa CY, Bowden BF. A marine verticillane diterpenoid from Cespitularia erecta. Nat Prod Res. 2008 Jan; 22(1):4852. https://doi.org/10.1080/14786410701589725

21. Ragasa CY, Tepora MM, Espinelli DH, Mandia EH, Rideout JA. Chromomoric acid derivatives from Tectona philippinensis. J Nat Prod. 2008; 71(4):701705. https://doi.org/10.1021/np0704304

22. Alea GV, Bowden BF, Ragasa CY. A new rearranged dolabellane diterpene from the soft coral Clavularia inflata. Nat Prod Res. 2008 June; 22(9):814819. https://doi.org/10.1080/14786410701640528

23. Ragasa CY, de Jesus JP, Apuada MJ, Rideout JA. A new sesquiterpene from Artemisia vulgaris. J Nat Med. 2008 Apr; 62(4):461-463. https://doi.org/10.1007/s11418-008-0253-0

24. Ragasa CY, Tsai P-W, Galvez C, Shen C-C. New carvotanacetone derivatives from Sphaeranthus africanus. Planta Medica 2009 Aug; 76(02):146-151. https://doi.org/10.1055/s-0029-1186031

25. Ragasa CY, Espineli DL, Shen C-C. New triterpenes from Barringtonia asiatica. Chem Pharm Bull. 2011 Mar; 59(6):778-782. https://doi.org/10.1248/cpb.59.778

26. Ragasa CY, Espineli DL, Mandia EH, Raga DD, Don M-J, Shen C-C. A new triterpene from Atalantia retusa Merr. Zeitschrift Für Naturforschung B. 2012; 67(5):426432. https://doi.org/10.5560/znb.2012-0026

27. Ragasa CY, Espineli DL, Shen C-C. A new triterpene from Barringtonia asiatica. Nat Prod Res. 2012 Oct; 26(20):1869-1875. https://doi.org/10.1080/14786419.2011.619187.

28. Ragasa CY, Espineli DL, Agoo EMG, del Fierro RS. Chemical constituents of Cinnamomum cebuense. Chinese J Nat Med. 2013 May; 11(3):264-268. https://doi.org/10.1016/s1875$\underline{5364(13) 60026-6}$

29. Ragasa CY, Torres OB, Bernardo LO, Mandia EH, Don M-J, Shen C-C. Glabretal-type triterpenoids from Dysoxylum mollissimum. Phytochem Lett. 2013 July; 6(4):514518. https://doi.org/10.1016/j.phytol.2013.06.010

30. Ragasa CY, Torres OB, Raga, DD, Mandia EH, Don M-J, Shen C-C. New triterpenes from the bark of Canarium asperum. Der Pharm Lett. 2014; 6(3):290-294

31. Ragasa CY, Espineli DL, Mandia EH, Don M-J, Shen C-C. A new triterpene from Glinus oppositifolius. Chinese J Nat Med. 2012 July; 10(4):284-286. https://doi.org/10.1016/s1875$\underline{5364(12) 60057-0}$

32. Ragasa CY, Ng VNS, Agoo EMG, Shen C-C. An isopimarane diterpene from Cycas sancti-lasallei. Der Pharm Lett. 2015; 7(9):168-171.

33. Ragasa CY, Ng VNS, Agoo EMG, Shen C-C. An Isoflavonoid Phtoalexin and a Sesquiterpene from Cycas wadei. Int J Pharmacog Phytochem Res. 2016 Mar; 8(4):686-689

34. Ragasa CY, Si M, Tan MCS, Pelobello DH, Don M-J, Shen C-C. A new sesquiterpene from Dendranthema grandiflora Flowers. Chem Nat Compounds. 2020 May; 56(3):436-439 https://doi.org/10.1007/s10600-020-03057-4 